\title{
Conservationists fear defeat on revised flood control policies
}

St Louis, Missouri. "How come we lose so many ball games when we're all so sincere?" This question, first posed by cartoon character Charlie Brown, is already being asked by conservationists as they face the prospect of defeat over efforts to introduce a radical new approach to flood control in the wake of the summer's Mississippi floods.

Whenever there has been a flood disaster in the United States, weighty reports have been produced and gestures made by govmore on natural wetlands and less on river engineering and levees. But, as those attending a 300-strong workshop on post-flood recovery organized in St Louis last week by wetland and flood-plain managers' associations were told by Californian environmental campaigner Ann Riley, "our control system still looks just like it did in 1942".

Farmers like a no-nonsense approach to flood control, and the Army Corps of Engineers likes building levees. As the federal government plans its \$7-billion recovery programme for the Mississippi, alliances between the two at local level are already threatening to outflank the more conservationist strategy favoured by Washington.

Conservationists are hoping for support from those who live in cities and from the Clinton administration. One of the president's environmental advisors, Will Stelle, told the workshop that the administration is receptive to their ideas. "It's time to recognize that the systems we have in place are not good enough", he said.

The White House and the Office of Budget and Management have already set up a workernment supporting a flood system based

ing group to look at the reconstruction of the levees built to hold back the Mississippi and protect the flood plain. And a directive was sent to all federal agencies in August instructing them to "keep alternative options open" as they deal with flood recovery.

According to Stelle, an interagency scientific assessment team is to be set up in a few weeks to oversee the recovery effort in the short term. And the White House has instigated a full review of the way in which rivers are managed whose outcome will set the tone for national policy for the next decade. But the window of opportunity for a change in the techniques of flood control is narrow, and some say it is already closing.

Gilbert White, 50-year veteran of the river restoration movement and founder of the Natural Hazards Center at the University of Colorado, says that critics of previous policies have about a year to achieve changes at the national level.

White has been pushing for a four-year moratorium on levee rebuilding, under which the federal government would promise to indemnify farmers for flood losses sustained during that period. But with the Mississippi already in flood again, and its saturated basin promising more trouble in 1994, that option looks expensive.

At its simplest, the conservationist case is that there are too many farmers living in the flood plain, and that the power of the river in flood is aggravated by levees built to protect crops. This power could be dissipated, they say, by restoring natural wetlands to absorb the water.

The farmers do not appreciate this point

\section{Rhône-Poulenc lifts Institut Mérieux stake}

Oxford. Rhône-Poulenc, the French stateowned chemicals and pharmaceuticals company which is soon to be privatized, is about to reinforce its position as the world's leading producer of vaccines by acquiring full ownership of the Institut Mérieux.

Rhône-Poulenc already owns 51 per cent of Institut Mérieux. Negotiations are now taking place to increase this to 100 per cent. Under the proposed deal, shareholders in Institut Mérieux will get 77 ordinary RhônePoulenc shares for every five Institut Mérieux shares they hold, valuing the outstanding stake at about US\$1.3 billion.

Institut Mérieux has played an important role in the development of vaccines technology, and was, for example, responsible for the production of the first European polio vaccine in the 1950 and the first commercial vaccine against meningococcal meningitis.
Its profitability and sales have increased in recent years, with new products such as paediatric vaccines against meningitis fuelling the surge. New products are in the development pipeline, and access to RhônePoulenc's deeper pockets will help Mérieux cope with high development costs.

According to a company spokeswoman the transaction "will strengthen RhônePoulenc's health business in the strategically important and fast growing area of preventative medicine". The new arrangements are expected to enhance the synergism that already exists between the two concerns, although there are no plans to merge Institut Mérieux activities with existing Rhône-Poulenc ones. Nor will existing deals already signed by Institut Mérieux with other companies be affected by the proposed transaction.

Mark Ward

\section{IMAGE UNAVAILABLE FOR COPYRIGHT REASONS}

\section{Last summer's floods: will the lessons be learnt}

of view, and the tension between the two sides is palpable. "Most of us have never met a real environmentalist", one farmer told last week's workshop. "Give us a practical alternative to levee reconstruction. Tell us how we're gonna survive".

The suggestion that natural wetlands would lessen the impact of major floods is hotly disputed, and will be a central subject of the research undertaken in the wake of the Mississippi flood (see Nature 364, 747; 1993). According to the Army Corps of Engineers, wetlands can have a marked impact in the containment of small floods, but not on the "hundred year flood" that arrived this summer.

According to Eugene Stakhiv of the corps' Institute of Water Resources at Fort Belvoir, Virginia, large areas of wetland would have reduced the height of that flood by only two or three feet, as previous months of heavy rain would have saturated the wetlands and removed their ability to absorb floodwater.

The corps' position on the rebuilding of levees is, however, ambiguous. Its Washington-based headquarters is still promising restraint, pointing out that only 12 repairs have been completed and 44 approved so far out of 1,100 damaged levees. But local corps offices boast of their speedy action to restore the flood barriers. One corps official says privately, for example, that on the upper Mississippi proper, all 37 levees will be fixed before winter comes.

Most levees have been breached only in one or two places and can be restored speedily and cheaply. Under current regulations, only around 300 levees are eligible for repair. But intense pressure from farmers and politicians is serving to persuade local corps commanders that many more levees are eligible, and should be fixed. It is this process, rather than any White House policy pronouncement, that is making conservationists feel they are losing the ball game once again.

Colin Macilwain 